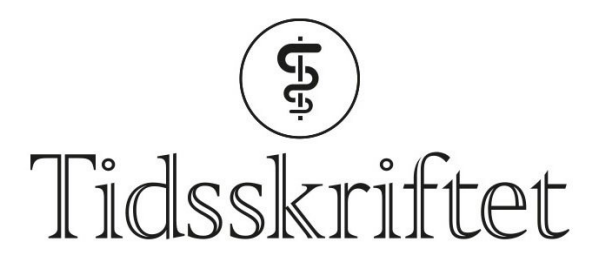

DEN NORSKE LEGEFORENING

\title{
Proteiner kan avsløre tarmkreft
}

FRA ANDRE TIDSSKRIFTER

ØYVIND STOPLE SIVERTSEN

Tidsskriftet

Vil påvisning av proteiner i avføringsprøver erstatte koloskopi som screeningundersøkelse for tarmkreft?

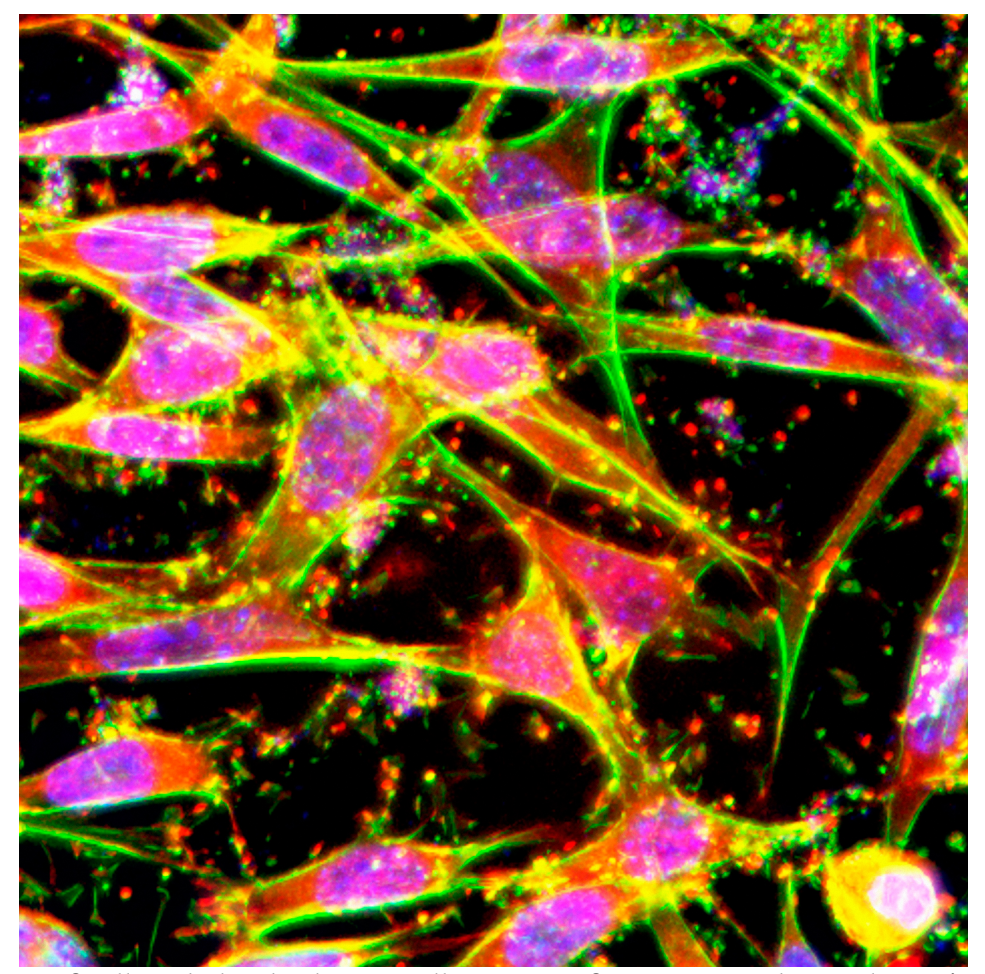

Kreftceller-kolorektalcancer. Illustrasjonsfoto: Science Photo Library / NTB scanpix

Kreftsvulster produserer andre proteiner enn friskt vev gjør. I utredning av mulig kolorektalkreft har man lenge benyttet tester som påviser hemoglobin i avføringen.

Teknologiske nyvinninger har nå gjort det mulig fra en avføringsprøve å sekvensere DNA fra proteiner som produseres av kreftsvulster. Slike proteiner finnes ikke i avføringsprøver fra friske individer.

I en studie som nylig er publisert i Annals of Internal Medicine, ble 315 avføringsprøver fra friske mennesker, fra pasienter med kolorektalkreft og fra pasienter med adenomer undersøkt med massespektroskopi (1). Til sammen 834 proteiner ble påvist. Ved bruk av klassifikasjons- og regresjonstreanalyser (classification and regression tree analysis, CART) og logistisk regresjon kom det frem at en kombinasjon av fire proteiner var best i stand til å skille kreftpasienter fra friske. Ved å kombinere funn av disse fire proteinene ved hjelp 
fekale immunokjemiske tester kunne man skille pasienter med tarmkreft fra friske mennesker, og man kunne skille mellom pasienter med adenomer og pasienter med kreftsvulster med høyere sensitivitet og spesifisitet enn ved påvisning av hemoglobin i avføringen.

- Fekale immunokjemiske tester med nye sensitive antistoffer kan brukes for å påvise kreft og adenomspesifikke biomarkører. På sikt kan dette gjøre tarmscreening med koloskopi overflødig og forvandle koloskopi til en i hovedsak terapeutisk prosedyre, sier Thomas de Lange, førsteamanuensis ved Universitetet i Oslo og tidligere leder av forprosjektet for screeningprogrammet for tarmkreft i Norge.

- Denne utviklingen vil måtte påvirke omfanget av det nasjonale tarmscreeningprogrammet som snart skal settes i gang, sier de Lange, som mener at en randomisert studie på befolkningsnivå vil bli helt nødvendig.

LITTERATUR:

1. Bosch LJW, de Wit M, Pham TV et al. Novel Stool-Based Protein Biomarkers for Improved Colorectal Cancer Screening: A Case-Control Study. Ann Intern Med 2017; E-publisert 21.11.2017.

[PubMed][CrossRef]

Publisert: 5. februar 2018. Tidsskr Nor Legeforen. DOI: 10.4045/tidsskr.17.1061

(C) Tidsskrift for Den norske legeforening 2020. Lastet ned fra tidsskriftet.no 